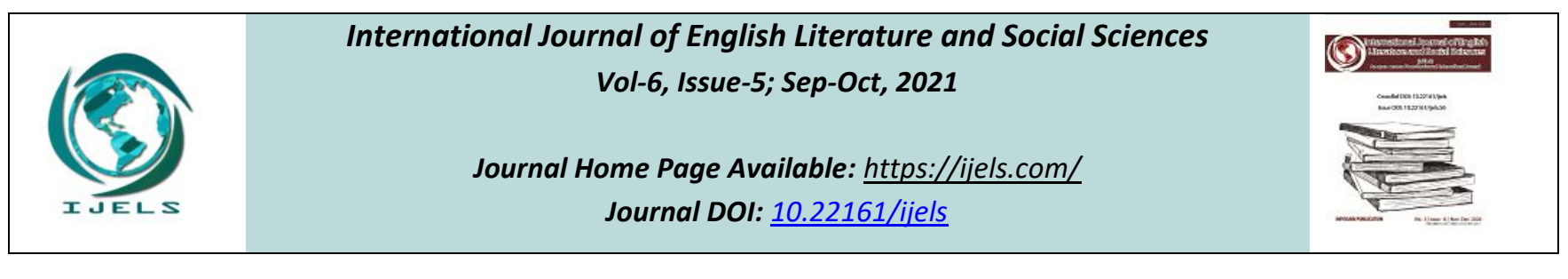

Peer-Reviewed Journal

\title{
Re-Visiting Rushdie's Fictional Oeuvre: An Overview of his Experimental Narrative Strategies that have Charmed Readers Worldwide
}

\author{
Dr. Yash Deep Singh
}

Dept. of English, Graphic Era Hill University, Clement Town, Dehradun, Uttarakhand, India

Received: 11 Sep 2021; Received in revised form: 08 Oct 2021; Accepted: 13 Oct 2021; Available online: 19 Oct 2021

(C)2021 The Author(s). Published by Infogain Publication. This is an open access article under the CC BY license

(https://creativecommons.org/licenses/by/4.0/).

\begin{abstract}
Salman Rushdie has maintained a lasting presence in the world of literature for a considerable span of over forty years and continues to enjoy a global celebrity status even today. His most characteristic trait as a novelist has been inventive experimentation with narrative strategies and literary devices, something that intrigues literary scholars and general readers alike. This article critically examines ten novels by Salman Rushdie (Grimus, Midnight's Children, Shame, Haroun and the Sea of Stories, The Moor's Last Sigh, The Ground Beneath Her Feet, Fury, Shalimar the Clown, The Enchantress of Florence, Luka and the Fire of Life) with the objective of tracing the experimental narrative strategies employed in each of these and the impact created by them upon the narrative. Further, the paper also reflects upon the correlations between Rushdie's convictions as a writer (including his individual world-view, sensibility and vision) and the specific narrative strategies devised by him to weave his fictional yarns.
\end{abstract}

Keywords - Narrative strategies, Literary devices, Narrative techniques, Innovation, Experimentation.

\section{INTRODUCTION}

A writer employs a specific narrative technique and takes recourse to a particular narrative strategy with a view to producing a specific desired effectiveness. In addition, the narrative technique resorted to in a novel goes a long way in lending artistic freshness and aesthetic effulgence to it. For nearly four decades (after winning the 1981 Booker Prize), Salman Rushdie has indubitably been an impressive presence on the world literary scene. Apart from exploring a broad spectrum of themes, the most distinguishing feature of Rushdie's potency as a fabulist is his capability to blend genres, bring together oriental and occidental narrative modes, break free from all constraints of chronological sequence, take recourse to experimental narrative methods and blur all boundaries between literature and the models of mass culture. Innovative experimentation with narrative strategies has been the core component lending literary ingenuity and a charming freshness to his narratives.
In his first published fiction, Grimus (published in 1975), Rushdie tries to launch the fundamental elements of his writing skills, his ability to merge genres and experiment with inter-textual blending from a wide range of sources. Grimus is an enticing combination of science-fantasy and folklore rooted in transcendental Sufi-mysticism, transporting the readers to surreal worlds and dimensions. Word-play and inclusion of anagrams feature in this novel as a mystifying maneuver. In the narrative of Grimus, 'Gorfs' inhabit planet 'Thera', which orbits around the star 'Nus' in the 'Yawy Klim' galaxy of the 'Gorfic Nirveesu', and their leader in 'Dota'. Now, this is actually a string of simple anagrams - the word 'gorf' is an anagram of frog, the name of their master is 'Dota' which is the anagram of Toad. They live on planet 'Thera', which is anagrammatically formed from the word earth. Similarly 'Nus', 'Yawy Klim' galaxy, and 'Nirveesu' can be deciphered as anagrams of Sun, Milky way galaxy and Universe respectively. The critic Uma Parameswaran observes that even the title of this book 'Grimus' is an 
Strategies

anagram of "Simurg, a mythical bird with esoteric associations in Arabic lore and Sufi writings" (Parameswaran 69). The book is replete with features characteristic of Science fiction such as Conceptual Technology (245), Scientist-poets (75) and a Gorfic-planet inhabited by alien creatures called Gorfs - which are life forms that "need no food, no water, no atmosphere, and possess only one intangible sensory tool which serves for sight, sound, touch, taste, smell and quite a lot besides: a sort of aura or emanation surrounding their huge, hard, useless bodies' (65). The novel also repeatedly mentions 'inter-dimensional trips to the alternative space-time continua (74-75), the elixir of immortality (20-21), and devices like Ion Eye (234), Water-crystal (234) and Subsumer (242). Notwithstanding the Sci-fi milieu in which this novel is set, the narrative of Grimus is endowed with profound philosophical undercurrents hinting at Sufi metaphysical quest or existentialist concerns, thereby giving the impression of being both picaresque and philosophical. The initiation of a quatrain from Farid-UdDin Attar's poem as a prelusion to this novel is a narrative strategy to implicitly hint that the entire narrative of Grimus shall be observed in the light of Sufi philosophy inherently associated with this novel. The journey of its protagonist Flapping Eagle portrayed in Grimus is not merely a literally physical voyage, but "an aesthetic, spiritual, and psychological voyage as well. It takes place on both an external and an internal level" (Peterson 6-7). Throughout the novel, epigrammatic aphorisms have been deftly inserted by Rushdie to hinge the narrative of Grimus with contemplative dimensions. A few examples of this nature can be cited from the text of the novel, such as: "the past is sure, it cannot be re-entered" (57); "Last chances, like first chances, come only once" (74); "A life always contains a peak" (81); The sands of time are steeped in new Beginnings (130); Wisdom is very rarely found in crowds (134); Self-deception operates at different levels (180) etc. Rushdie thus weaves the narrative of Grimus by intertwining Science Fiction narrative strategies with philosophical and existential streaks.

In Midnight's Children, Rushdie structures the narrative in a fashion in which stories are traditionally told in India. The absence of a linear plot, the swoops, the spirals, the digressions, and the reiterations, - so characteristic of the traditional oral-narratives of India, are all there in Midnight's Children. Rushdie blends with the core-story of Midnight's Children, a big number of anecdotes, historicalevents, public-gossips and references to renowned as well as notorious public figures in the form of digressions that branch from the main story. This comic allegory of Indian history (extending from 1915 to 1978) revolves around the lives of narrator-protagonist Saleem Sinai, his family members and the 1000 children born on the night of the declaration of Independence in 1947 within the territorial limits of India. Midnight's Children gives the impression of being an autobiography of the fictional protagonist Saleem Sinai, but the events in the life of Saleem or his family members are connected to contemporary national events, and so the novel narrates the history of modern India through the depiction of events that take place in the life of Saleem Sinai and his ancestors. Saleem's personal history is portrayed as a microcosm of the national history of India. It encompasses nearly all the major events in the recent history of Indian sub-continent, including the Jallianwalla Bagh incident at Amritsar (1919), the 'Quit India' movement (1942), Indian Independence and partition (1947), the language riots between Gujrati and Marathispeaking people in Bombay (1956), the imposition of Ayub Khan's Martial law in Pakistan (1958), the Indo-Chinese ware (1962), the death of Nehru (1964), the Indo-Pakistan wars in the Rann of Kutch, in Kashmir and then on the Western border in September 1965, the emergence of Sheikh Mujibur Rehman as the leader of Bangladesh and the military action by West Pakistani forces in East Bengal (1971), the conflicts between the Indian and Pakistani troops in 1971, the declaration of emergency by Prime Minister Indira Gandhi (1975) and the defeat of Indira Gandhi's Congress party by the newly formed Janata Party in 1977. By relating private lives to public events, Rushdie explores the ways in which history is given meaning through the retelling of 'individual' experience. Midnight's Children is thus an attempt to recreate Indian history from an individual's perspective, as against the authoritarian official version of history. Rushdie states in any essay in Imaginary Homelands that:

It is clear that re-describing a world is the necessary first step towards changing it. And particularly at times when the state takes reality into its own hands, and sets about distorting it, altering the past to fit its present needs, then the making of the alternative realities of art, including the novel of memory, becomes politicized. ... Writers and politicians are natural rivals. Both groups try to make the world in their own images; they fight for the same territory. And the novel is one way of denying the official, politicians' version of truth. (13-14).

Subverting the officially documented versions of history and bringing into question any absolute historical certainty, Rushdie tries to enter microcosmically into the recent history of India from the angle of individual-perspectives of his fictional protagonist Saleem Sinai and the members of his family; piecing together a version of history (through their subjective experiences of national events) like multiple 
other possible versions of history, none of which can claim to be complete or ultimate.

In an attempt to make Midnight's Children a truly postcolonial book that "infuses the tempo of Indian life into English expression" (Raja Rao 5), Rushdie deviates from the calm, mild, classicist and linguistically orthodox manner of using it and experiments with language by "getting away with the use of the mongrel street language of cities, daring to translate idioms and metaphors with audacious literalness and perpetrating bilingual puns mediated by no apology, no footnotes, no glossary" (Mukherjee 10). In an essay in Imaginary Homelands Rushdie too states the need of remaking English language to suit our own purposes, saying that — "To conquer English may be to complete the process of making ourselves free" (17); and Midnight's Children best illustrates Rushdie's strategy or method of decolonizing and domesticating the English Language. The English used by the Rushdian fictional characters in Midnight's Children is abundantly sprinkled with pure vernacular colloquial expressions and phrases, and even some commonly spoken abusive slang that are all frequently used in day-to-day communicative language by the common people in India. A few examples from the text can be cited: "Chhi, Chhi", Padma covers her ears... (319) ; "What a world, baapu-re!" (458); Green chutney on chillipakoras (211); "Come on Phaelwan" (239); ... amid the cacophony of hawkers selling earthen animals and cups of chaloo-chai ... (451); 'Good afternoon, Begum' (457).This is Rushdie's method of re-molding the colonial English to new, inventive, need-based usages that seems more befitting to convey the Indian sensibilities with a native flavor. Rushdie subverts the notion of the purity of King's English by resorting to hybridized English words likeactressy, doctori, dupattalss, writery-shitery, joke-shoke whistling-shistling Club-shub tea-cup-kissery etc., and incorporating transliteration of vernacular idioms such as : 'donkey from somewhere', 'madman from somewhere', 'our little piece-of-the-moon' 'whatsitsname' etc. so deftly that it gels well with the texture of the novel, yielding a remarkable Indian flavor to the book.

While Midnight's Children focuses on post-independence Indian history, Shame is primarily concerned with Pakistani political events during 1970s and 1980s. Fact and fantasy have been commingled skillfully in the narrative of Shame. Many of the fictional characters that figure in the novel are thinly veiled portrayals or caricatures of real politicos or Army-Generals of Pakistan, as Novy Kapadia points out: "Iskandar Harappa is Zulfikar Ali Bhutto, Raza Hyder is Zia-ul-Haq, Rani Harappa is Nusrat Bhutto, Arjumand Harappa is Benazir Bhutto, General Shaggy Dog is former President Yahya Khan and Sheikh Bismillah is Sheikh Mujibur Rahman" (Kapadia 245). A series of authorial asides recur throughout Shame, by means of which the author talks directly or seems to talk directly to the readers. Such authorial intrusions into the fictional narrative selfreflexively expose the thoughts, memories, personal ruminations or anecdotes and deliberations of the author, connected with the process of writing Shame. For example, the novel depicts the radical Islamization of State ( of Pakistan), under the regime President Zia-ul-Haq through the fictional story of General Raza Hyder (veiled portrait of Zia) who makes 'Islam' an explicit basis of state policy and conduct; but this fictional description is supplemented with an authorial non-fictional intrusion to project author's personal ridicule for such misuse of theology, thereby giving a clue to readers to interpret the fictional episode in the light of the authors intentions and clarify the authorial perspective. An excerpt from Shame would elucidate Rushdie's use of authorial intrusions as a narrative strategy:

May I interpose a few words here on the subject of the Islamic revival? It won't take long. Pakistan is not Iran ...it's my opinion that Pakistan has never been a mullah-dominated society. So-called Islamic 'fundamentalism' does not spring, in Pakistan, from the people. It is imposed on them from above. Autocratic regimes find it useful to espouse the rhetoric of faith, because people respect that language, are reluctant to oppose it. This is how religions shore up dictators; by encircling them with words of power, words which the people are reluctant the see discredited, disenfranchised, mocked. (250-51)

While most of the major characters in Shame are thinly veiled portraits of real-life politicos or Army Generals of Pakistan; the protagonist of the novel, Sufiya Zinobia is purely fictitious, portrayed by Rushdie as a personification of shame. Sufiya Zinobia "was too easily shamed" (90) right from the time of her birth as a "wrong miracle" (89), being born to parents who hoped for her to be a male child. Sufiya's humiliation starts from her very moment of birth and right from a very early age she feels the shame of being born as a girl in a society which values boys along. Her own mother laments: "He (Raza) wanted a hero of a son; I gave him an idiot female instead ... she is my shame" (101). Sufiya grows among perpetual humiliation, deprived of parental attention and "her spirit parched for lack of affection" (121). This humiliation and sense of shame ultimately turns her into a beast which unleashes a reign of terror throughout the country, mercilessly tearing off the heads of people after hypnotizing them. Such a portrayal of the fictional character, Sufiya Zinobia, in Shame is actually a strategy of Rushdie to fictionally exemplify the idea that extreme repression and suppression finally leads to a reactive eruption in the form of a deadly beast of violence. 
Expatiating upon his motive behind the formulation of such a character - a combination of "Beauty and the Beast" (158), Rushdie states in an interview with Gordon Wise:

I suppose Sufiya Zenobia came about because I wanted some kind of incarnation of the ideas the book dealt with. You have to make the connection between shame and violence. If you push people too far and if you humiliate them too greatly, then a kind of violence bursts out of them. I wanted somehow to enclose that idea inside one person. (59)

Freudian psycho-analytical theories verify the above stated idea of Rushdie. According to Freud, the fundamental reason behind hysteria is "the presence of massive repression and the development of a symptom pattern that indirectly or symbolically express the repressed needs and wishes" (Mischel 95). It can therefore be said that the narrative of Shame underscores psycho-analytic theories as well, through the portrayal of the fictional Sufiya Zinobia.

Haroun and the Sea of Stories (1990) was published a year after a death verdict was issued against Rushdie, by the Iranian cleric Ayatollah Ruholla Khomeini, forcing Rushdie to go into hiding under the round-the-clock protection of The Scotland Yard Special Branch. Although this fictional work of Rushdie can primarily be read as a children's novel (hugely entertaining with its fairytale world of water genies, floating gardener, fish with mouths all over their bodies and mechanical flying birds), this book allegorically deals with serious concerns. Presented in the guise of a fable, and the novel begins with fairy-tale gambits like a typical children's story: "There was once, in the country of Alifbay, a sad city, the saddest of cities, a city so ruinously sad that it had forgotten its name. It stood by a mournful sea full of glumfish, which were so miserable to eat that they made people belch with melancholy...." (15). In spite of having a seemingly fairy-tale structure, this book is grounded in the archetypal issues of freedom of expression and imagination versus State control (that smothers it). The forcible silence, imposed on the inhabitants of the Chup city by their CultMaster Khattam Shud (in Haroun and the Sea of Stories) is indicative of censorship that curbs the creativity and freethinking of authors, analogous to the restrictions and bans imposed on the creative expression of Rushdie. In a way, Rushdie's writing of this novel becomes an act of resistance against the attempts to stifle him, either through death verdicts or through bans and bureaucratic restrictions imposed on him. Like a true fable, Haroun and the sea of stories neither pontificates nor teachers; rather it seeks to direct the attention of readers towards certain aspects of real-life, which a reader needs to grasp from the text by reading in between the lines. It is not very difficult to decipher (in this text) the Democracy versus Autocracy debate behind the description of battle between Guppees and Chupwalas. The vivid descriptions related to KhattamShud and his domain - the Land of Chup, expose the mechanisms of dictatorship that oppress free speech and freedom of the imagination, as imaginative-liberty seems dangerous to authoritarian objectives. In Haroun and the Sea of Stories Rushdie again experiments with the narrative strategy of blending elements of fairytale and sciencefiction. Certain characters of this novel like the Hoopoe bird and winged mechanical horses have mechanical or computerized electronic organs; whereas several other characters like Water Genie named Iff, Floating Gardeners, Plentimaw Fishes etc. are all fairy-tale creatures. Towards the end of this story, sophisticated mechanical devices like immense super-computers and gigantic gyroscopes meant for controlling the rotation of the moon, in order to preserve the eternal daylight and perpetual darkness simply turn dysfunctional due to the magical effect of 'Wishwater' that could make desires come true. Khattam's poison factory (in Haroun and the Sea of Stories) with its devices of 'converting mechanical energy into electrical energy by means of electromagnetic induction' (163) belongs to the realm of science fiction. Haroun is aided by a bird with a brain-box with memory-cell and command module; he has a 'bite-a-lite' torch to illuminate his path, but ultimately what saves him, rescues Princess Baatcheat and purifies the ocean is not technology or science-fiction strategies, but a bottle of 'wish-water' of pure fairy-tale variety (Mukherjee 194). The novel also mentions "Machines too Complicated To Describe (or M2C2Ds)" (90), which are indicative of some highly advanced technology. The narrative of Haroun and the Sea of Stories is thus structured by interweaving elements of fantasy, fairy-tale and science-fiction that lead to an allegorical story which at the surface level appears to be a traditional fable or fairy-tale meant for entertaining kids, but on a closer scrutiny reveals very serious and mature underlying concerns regarding freedom of speech or expression.

In The Moor's Last Sigh published in 1995, Rushdie focuses microcosmically not on the bigger sections of Indian populace, but on the micro-minorities of India, the Catholics having ancestral ties with the Portuguese discoverers of India and of the Cochin Jews with their links to Moorish Spain. The novel spans four generations of the De Gamas, from the last decades of the nineteenth century until the very recent past, the 1990's. At the centre of the novel features the protagonist-narrator Moraes Zogoiby, whose mother Aurora Zogoiby, descends from India's Portuguese invaders while his father, Abraham Zogoiby, is one of the last Jews of Cochin in South India. 
For Rushdie, the very idea of India is palimpsestic in nature, a product of sedimentation of layer upon cultural-layer deposited by successive new settlements of outsiders, who after a few generations have become wholly assimilated in the cultural-atmosphere of this land. Looking upon India as a site of multiple 'presences', as a palimpsestic nation having many layered cultural and historical foundations, it is the idea of multiple beginnings that the text endorses. This Rushdian ideal of an Indian nation - where even the tiniestminorities are considered to be an integral part of Indianness and differences are cherished, rather than subdued - is most accurately projected through the fictional paintings of Aurora Zogoiby. To project his personal vision, Rushdie experiments with the narrative technique of ekphrasis, the conduct of narration through the description of imaginary works of art. Through paintings, "the prophetic and historical imagination of Aurora dominates the book" (Coetzee 322). Inspired by the harmonious multiculturalism of Moorish Spain, Aurora paints upon her canvasses a utopian world that she herself terms 'Mooristan'. This Mooristan was " a place where worlds collide, flow in and out of one another, and washofy away... One universe, one dimension, one country, one dream, bumpoing into another, or being under, or on top of. Call it Palimpstine" (226). This pictorial utopia of Mooristan is actually a suggestive rendition of Aurora's version and Salman Rushdie's vision of India.

The Ground Beneath Her Feet (1999) is a novel in which the story-line revolves round Vina Apsara, a fictional Rockstar. The life of Vina Apsara is intersected now and then by a paparazzi photographer 'Rai' alias Umeed Merchant who has been in love with her since his adolescence. Overthrowing the elitism of modernist high art by recourse to the models of mass culture, Rushdie has designed a postmodern pattern of narrative in The Ground Beneath Her Feet by liberally sprinkling references to popular Rockmusic lyrics, song titles and album titles. The protagonist Vina Apsara evokes a mass-celebrity image shattering all boundaries of nationalities and regionalism and binding the entire world together under such common spell that "reminds the reader of the queen of pop music, Madonna" (Adami 32). The role of Music and Rock-Stars as catalysts of Globalization is the core thematic-import of The Ground Beneath Her Feet. Rushdie has deftly modeled Vina Apsara as a star whom crowds knows "in the streets of Yokohama, Darwin, Montevideo, Calcutta, Stockholm, Newcastle, Los Angeles" and fictionally projected her demise as a misfortune that people from different corners of the world regarded a personal bereavement, "momentarily reinventing their sense of a larger kinship, of their membership in the family of mankind" (529).
Narration through the medium of 'photographs' is an ekphrastic narrative technique deployed masterfully by Rushdie in this novel. In his portrayal of the visual-narrative by means of the photographs clicked by the novelistic character Rai, Rushdie tries to prove that "a camera can see beyond the surface, beyond the trappings of the actual, and penetrate to its bloody flesh and heart" (87). Rai takes the photographs of his mother and father, when they die and tries to decode the silent messages that such photographs convey without relying on any verbal or semiotic medium. Rai looks upon photography as a medium to see, read and understand the metaphoric beneath the factual, the truth and the meaning beyond the surface, therefore he starts experimenting with several uncommon different dimensions of photography, using it as a tool for defamiliarization. Exploring fresh facets of de-familiarization through photographic mode, Rai, becomes a photographer of exits and starts taking photographs of strangers' funerals. To these photographs of funeral practices, Rai adds his own de-familiarizing perspective and states:

In my stolen photographs - for the photographer must be a thief, he must steal instants of other people's time to make his own tiny eternities - it was this intimacy I sought, the closeness of the living and the dead. The secretary staring through eyes made garish with grief at the body of his great master dressed in fire. The son standing in an open grave, holding his father's shrouded head in his cupped hand, laying it tenderly upon deep earth. (232-33)

By depicting the photographic-experimentations of Rai in The Ground Beneath Her Feet, Rushdie masterfully employs photography as a narrative medium for effective defamiliarization. By means of his photographic angle of perception, Rai perceives familiar things from a fresh perspective in such a manner that they seem new and interesting. Gavin Keulks makes the following observation regarding the use of photographs as a mode of narration in The Ground Beneath Her Feet:

Photography, in this construction, is a 'kind of digging' (155), and with his camera he essentially maps the topography of both his cultural and emotional landscapes. Irreconcilable emotions complicate this metaphorical mapping, as Rai's narration is circular rather than linear, therapeutic instead of progressive. (Keulks 248-49)

Ultimately, both narration and photography, both the voice and the vision, are means to salvage what is lost, transforming it into living memory. Like written or spoken words, photographs too act as an effective mode of 
narration, conveying information even more intensely, so that it is not only understood, but even felt; as Rai states in The Ground Beneath Her Feet: "Monroe's flying skirt, the burning girl in Indochina, Earthrise-which actually become experiences, part of the collective memory of the human race" (513-14).

Rushdie's eighth novel Fury (2001), all set in New York, is an insightful critique of contemporary American milieu, intensely capturing every nuance of New York City and American psyche. The entire novel is refracted through the consciousness of its fury-tormented protagonist, Malik Solanka, who comes to America scouting around for peace but finds none, rather he senses the seething fury and bonedeep resentments smouldering deep within the American society, in spite of the fact that the country "boiled with money" (03). Loading the narrative of this book with passing references to contemporary American politicos, CNN news reports, Hollywood movies, American brandnames as well as movie and music icons of contemporary America, Rushdie masterfully blends real with the fictional. The novel was published in 2001, few months after Rushdie departed from London and settled in America, making it his new home; and as the real life circumstances of Rushdie himself are tangentially mirrored in the narrative of Fury, the novel gives an impression of being a book containing autobiographical touches, while the central character of Fury, Malik seems to function like an 'author surrogate' or mouth-piece of Rushdie himself. At multiple spots in the narrative of Fury, there figure riff like improvised comments on various facets of contemporary American life, presented in the narrative as interior-monologues of Malik Solanka, but such asides give the impression of being authorial comments made by Rushdie himself. The growing materialism and dehumanizing superficiality in contemporary American society, and in inverse proportion to it, the deterioration in human-values and spiritual spontaneity has been spotlighted in the depictions of the interior-monologues of the protagonist, as in these lines:

But now living women wanted to be doll-like .... These living dolls, these strings-less marionettes, were not just "dolled up" on the outside. Behind their high style exteriors, beneath that perfectly lucent skin, they were so stuffed full of behavioral chips, so thoroughly programmed for action, so perfectly groomed and ward robed, that there was no room left in them for messy humanity. (74)

Fury also paints a realistic portraiture of the postmodern media-molded milieu of America in which the "new language of commercialism" (101) holds sway over both intellectualism and creativity. The novel fictionally exemplifies the ugly fact that consumer-capitalism led by the logic of the market, forces creative-genius to bow to and compromise with the dictums of global mass-consumption. At the outset of his doll making career, Malik Solanka creates a doll by the name of Little Brain, and develops a series of late- night television program in which the doll interviews great philosophers. This first late-night series of Little Brain is made more or less exactly as Malik Solanka desires. Contrary to expectations, the series becomes a smash hit on television and Little Brain gets elevated to the status of a T.V. celebrity. Eventually the T.V. channel's executives start intervening in the story and characterization of this T.V. series and gradually Solanka losses creative control over it. Consequently, from being an intellectual "highbrow" format in which the leading character (Little Brain) could "hold her own with Erasmus or Schopenhauer" - the eminent philosophers, the show gets transformed by an anonymous crowd of ghost-writers into a banal comedy, presided over by a "tawdry celebrity" with the intellect of a slightly over-average chimpanzee" (98). Helplessly witnessing the metamorphosis of his once favourite Little Brain, Malik Solanka gets seethingly furious and frustrated, as "this was not the life he had imagined for her" (98). The narrative of Fury thus fictionally re-creates the unfortunate real-world scenario where creativity, intellectual principles and ethics often get engendered by ever-growing propensity towards untrammeled commercialism and materialistic compromises for monetary greed.

Grounded substantially in historiography, Salman Rushdie's Shalimar the Clown (2005) chronicles the recent history of Kashmir, detailing with absolute preciseness its deterioration into a disturbed conflict zone. Journalistic non-fictional accounts are liberally inserted into the fictional narrative, rendering it the texture of a documentary. Superimposed on realistic settings, the narrative of Shalimar the Clown seems convincingly real and is replete with thought- provoking scenes depicting the atrocities faced by ordinary Kashmiri folks, at the hand of both fanatic terrorists and the Indian army. Visual depictions and pictorial presentations are among the consistent narrative techniques exploited in Shalimar the Clown by Rushdie. Such pictorial narration of atrocities is supplemented with satirical commentaries by the omniscient authorial voice, evoking concern and sympathy for Kashmiris in the minds of the readers. The following lines from the text can be pertinently cited:

Three hundred and fifty thousand Pandits, almost the entire Pandit population of Kashmir, fled from their homes and headed south to the refugee camps where they would rot, like bitter fallen apples, like the unloved, undead dead they had become. ... the Pandits of Kashmir were left to rot in their slum 
camps, to rot while the army and the insurgency fought over the bloodied and broken valley, to dream of return, to die while dreaming of return, to die after the dream of return died so that they could not even die dreaming of it, why was that why was that why was that why was that why was that. (36971)

The critic Andrew Teverson observes that Rushdie's question-asking narrative style in Shalimar the Clown serves at least two constructive political functions. In the first place, the very act of posing the question, of bearing witness to atrocity, constitutes a potent political gesture: a demand for attention and a demand for redress. In the second place Rushdie's question asking also functions as a plea: " a plea to the Indian army not to exploit the situation in Kashmir, a plea to moderate Muslims to seek to reform their religion, and a plea to European and North American politicians to create a global political context that helps rather than hinders their progress" (Teverson 225).

The Enchantress of Florence (2008) is a novel modeled by Salman Rushdie on a structural pattern of genre-fusion of legends, fairy-tales and history. This book is steeped in extensive research on interconnections between the history of Medieval India and Renaissance Europe. The Enchantress of Florence is not just a book about a journey 'West' (by the Mughal princess Qara Koz), but also about a journey 'East' (by her alleged descendent, Mogor dell' Amore who serves as a familial link between Mughal India and Florentine Italy). Rushdie maintains an orient- occident balance by deploying the narrative strategy of unfolding his story from two beginnings - one in Fatehpur Sikri during the reign of Indian Emperor Akbar (around the later phase of the $16^{\text {th }}$ century) and the other, half a century earlier in Florence, Italy in the age of Giuliano de' Medici (towards the end of the $15^{\text {th }}$ and the early quarter of the 16th century). The events that unfold episodically in this novel are depicted taking place in two different settings half a world apart and at two moments in time which are half a century apart; hence, the narrative-focus keeps shuttling back and forth, both in place and time, all through the novel. The reader is immersed for nearly thirty pages in the events and milieu of Akbar's court at Fatehpur Sikri in India, and then the story shifts to the other half of the world, in Renaissance Italy, fifty years back in time.

The fictional Akbar of The Enchantress of Florence is developed by Rushdie by infusing within the historical character of Mughal Emperor Akbar, a sensibility and vision, analogous to Rushdie's individual ideologies and stance on religious, cultural, philosophical or socio-political aspects of human life. Emperor Akbar has been portrayed by Rushdie, not just as a grand warrior and the greatest
Mughal monarch, but also as a remarkable philosopher whose ruminations on various theological issues aim at creating a synthesis of different belief systems and end forever, "the quarrel over God"(347), and above all, as a pedagogue and proponent of a "culture of inclusion", in which "all races, tribes, clans, faiths and nations would become part of the one grand Mughal synthesis, the one grand syncretization of the earth" (317). Such a fictional portraiture of Emperor Akbar is instrumental in the projection of the vision of Rushdie to usher in the worldview of a heterogeneous, mixed world in which all constraints of latitudes and longitudes get subverted, giving way to the synthesis and unification of both the hemispheres; and where every individual has the liberty to think and express himself freely. Expatiating upon this narrative strategy of fictionally presenting the historical character of Akbar in a way that it functions in the novel as a 'spokesman' for the author, Ursula K Le Guin remarks:

Rushdie's Akbar is imperial, intelligent and very likeable, a marvelous spokesperson for his author. ... Akbar is the moral centre of the book, its centre of gravity, and provides its strongest link to the issues that have concerned Rushdie in his works and his life. (Guin 6-7)

Also, various sub-plots are inserted into the text, making the narrative hypodiegetic (a secondary narrative embedded within the primary narrative) in texture. Rushdie also touches on several other contemporaneous events that took place during the $15^{\text {th }}$ and $16^{\text {th }}$ century, in Central Asia, Mongolia, Samarkand and England, by adhering to the impressionistic mode of narration. Either by means of authorial asides branching from the core-story or else through the musings of various major characters, the novel impressionistically dishes out accounts pertaining to Akbar's Mongol and Chaghatai lineage from Ferghana, military pursuits of Babar at Samarkand, defeat of Humayun at the hands of Askari, forcing him to flee to the cold "badlands of Kandahar" (110), the clashes between the Persian King Shah Ismail and Ottoman Sultan Bayezid II, as well as the manifold political, social and religious upheavals in Florence that resulted from the rebellious designs of Republicans and the pontifical interventions of Leo X, during the regime of Medici Dukes. Intercontinental history thus serves as a springboard for enormous play and counter-plays of imagination in The Enchantress of Florence.

Rushdie liberally resorts to magical realism in this book, conjuring up a fictional world, in which the unreal inhabits the world of reality, thereby transporting the reader to a time "before the real and unreal were segregated forever and doomed to live apart ..." (324). The two major female 
characters of this novel Jodha and Qara Koz are both portrayed in a magical realist vein by Rushdie — Jodha as an imaginative invention by Akbar while Qara Koz as an apparition. Materializing out of the fantasies of Akbar, his most beloved but imaginary Queen Jodha is "a dream made flesh, a traveler from the world of 'khayal', fancy, whom he had brought across the frontier of the real" (308).

When Akbar asks his favorite painter Dashwanth, to bring Qara Koz to life via paintings, he falls so deeply in love with this bygone woman that he becomes part of his canvas, turning himself into an imaginary being and crossing the borderline between the worlds of imagination and reality to get "released into the only world in which he now believed, the world of the hidden princess, whom he had created and who had then uncreated him" (127). Use of magical realism as a narrative technique also exudes from the depiction of the semaphore waters of Anup Talao that can send warnings when the kingdom was in trouble by growing "choppy and un-calm even though there was no breeze" (327). The Enchantress of Florence thus evinces Rushdie's caliber to deploy the experimental narrative technique of amalgamating variegated strands of history, fantasy, fairy-tale, legend, folk-tale, and magical realism, along with traditional storytelling gambits - all in sync with one another - to shape up a consummately balanced fictional work.

Staying abreast with the changing trends and tastes of present day digitized world, Salman Rushdie further juggles with cyber-culture in his postmodern novel Luka and the Fire of Life, by blurring the boundaries between fables, fairy-tales and video-games. To tune in with the changed literary taste and postmodern sensibility of today's teenagers who have a penchant for cyber-culture consoles, the lexicon and settings of video games have been tailored by Rushdie to suit fairy tale motifs. It is a book written particularly for Rushdie's younger son Milan (aged 12 in the year of this book's publication) and for all those twentyfirst century children, whose worldview is coloured with virtual-realities created by digital consoles, popularly called video games.

This book is a sort of companion of Haroun and the Sea of Stories, Rushdie's first book for children, published ten years before Luka and the Fire of Life. Although set with the same cast of fictional characters depicted as Luka's family members (father, mother and elder brother), the two books display pronounced differences in imaginative milieu and narrative pattern. While the first children's book by Rushdie narrated a fairy-tale, this second children's book narrates a video game. As done earlier in the case of Haroun and the Sea of Stories, Rushdie has demolished the boundaries between Adult Literature and Children's' Literature in Luka and the Fire of Life again, by embracing the worldview of a twelve-year- old child but conveying through it numerous subtle messages for adult readers. The protagonist of this tale is an adolescent named Luka, who "lived in an age in which an almost infinite number of parallel realities had begun to be sold as toys" (p.11) and "had joined imaginary communities in cyber-space" (p.12) through his penchant for video-game consoles. Rashid Khalifa, the fictional father of Luka, has brought him up on a diet of magical tales that suddenly stop flowing from his lips one day, as he slips into a coma. The only option left to save his father was to bring for him "The Fire of Life that burns at the top of the Mountain of Knowledge" (p.34). Hence, Luka decides to venture into the 'World of Magic' for retrieving the fire of life, accompanied by his two loyal pets - Dog the bear and Bear the dog. Analogous to the picaresque genre of fiction anchored in journey-motif, a substantial portion of this book is set in digital settings of cyber-consoles and video-games and the protagonist Luka embarks on a journey through the magic world, encountering a slew of phantasmagorical obstacles along the way, to steal the 'fire of life' for saving his father from death. But in this digitalized fairytale narrative, the magical world has different 'levels' analogous to video-games through which Luka makes his way, thus giving the readers a feel of cybernetic entertainment and thrill. While progressing through these levels, Luka confronts challenges, acquires new friends and a magical Flying Carpet of King Solomon that "could carry any number of people... and could grow until it was immensely large" (p.86) . He also comes across all of the antique deities worshipped by human cultures several ages ago, that are no more worshipped by modern people, causing them to slip into oblivion, but just preserved by the magical imagination of Luka's father Rashid. Luka surmounts nine 'levels' before reaching his final goal; every time he manages to cross a 'level', he is rewarded with the gift of extra 'lives' to spend, much like one would gain by accumulating points in a video-game. The novel is interspersed with magicrealism that helps in tailoring a fictional narrative to resemble a digitalized video game, as in this extract from the book:

He (Luka) grabbed lives in great handfuls and stuffed them into his pockets, whereupon, with a little ting they dissolved, and became a part of him; and this was when he noticed the change in his eyesight. A little three-digit counter had somehow become lodged in the top left-hand corner of his field of vision; and the numbers kept going up as he swallowed or absorbed, his many lives, making a low whirring noise as they did so (pp.50-51)

Megan L. Musgrave calls Luka and the Fire of Life it a "Ludic Text" that is game or play-oriented, pointing out that 
Strategies

the book's narrative structure borrows from Super Mario Brothers, Sonic the Hedgehog, and other games (Musgrave, p.239).This narrative strategy of creating a postmodern digitalized folklore, bridges the generation gap between oldfashioned storytelling and the twenty-first century digital modes of entertainment.

\section{Conclusion}

Whether admired or criticized, the fact remains that Salman Rushdie - with his obstinate commitment to struggle for freedom of expression, his allegiance to decentralization and decolonization, his boldness to challenge conventional order and his inclination to champion the empowerment of the marginal - is a writer who cannot be ignored. The umbilical cord of Salman Rushdie's fictional oeuvre remains un-severed from his cosmopolitan sensibility of imagining and creating a World without frontiers in which the dictates and dictums of theocracy or autocracy are subverted, free-speech is never strangulated, variegated cultures commingle flowing in and out of one another and no ideological dogmas impede the way of hybridization or intermingling of multiple cultures. Rushdie's innovative narrative strategies ranging from genre-blur to genre-fusion and his experimental narrative techniques deserve substantial credit in the creation of literary assets to World Literature that have enchanted millions worldwide.

\section{REFERENCES}

[1] Adami, Esterino. Rushdie, Kureishi, Syal: Essays in Diaspora. New Delhi: Prestige, 2006.

[2] Coetzee, J.M. "Palimpsest Regained". Contemporary Literary Criticism. Vol. 100. Ed. Deborah A. Stanley. Detroit: Gale, 1997. 319-24.

[3] Guin, Ursula K Le. "The Real Uses of Enchantment". The Guardian. 29 March 2008:110.<http://www.guardian.co.uk/books/2008/mar/ 29/fiction. salmanrushdie $>$.

[4] Kapadia, Novy. "Narrative Techniques in the New Indian Novel". The New Indian Novel in English: A Study of the 1980s. Ed. Viney Kirpal. New Delhi : Allied, 1990. 239-50.

[5] Keulks, Gavin. "Preferring the composite darkness : Trauma Theory and Narration in The Ground Beneath Her Feet". Rushdie the Novelist: From Grimus to The Enchantress of Florence. Ed. Meenakshi Bharat. New Delhi: Pencraft, 2009. 247-63.

[6] Mischel, Walter, Yuichi Shoda, and Ronald E. Smith. Introduction to Personality: Toward An Integration. New York: John Wiley, 2004.
[7] Mukherjee, Meenakshi. Introduction. Rushdie's Midnight's Children: A Book of Readings. Ed. Meenakshi Mukherjee. Delhi : Pencraft, 2003. 9-27.

[8] Musgrave, Megan L. "Gaming as Civic Engagement in Salman Rushdie's Luka and the Fire of Life". Children's Literature Association Quarterly. Vol 40, Num 3 (2015): 238-256.

[9] Parameswaran, Uma. Salman Rushdie's Early Fiction. Jaipur : Rawat Publications, 2007.

[10] Peterson, Margareta. "Grimus and the Alchemical Tradition". Salman Rushdie: New Critical Insights. Ed. Rajeshwar Mittapalli and Joel Kuortti. New Delhi: Atlantic, 2003. 1-29.

[11] Rushdie, Salman. Imaginary Homelands: Essays and Criticism 1981-1991. London: Granta, 1991.

[12] Rushdie, Salman. Grimus. 1975. London: Vintage, 1996.

[13]---. Midnight's Children. 1981. London: Vintage, 1995.

[14]---. Shame. 1983. London: Vintage, 1995.

[15]---. Haroun And The Sea Of Stories. 1990. New Delhi: Penguin, 1991.

[16]---. The Moor's Last Sigh. 1995. London: Vintage, 1996.

[17]---. The Ground Beneath Her Feet. 1999. London: Vintage, 2000.

[18]---. Fury. 2001. London: Vintage, 2002.

[19]---. Shalimar The Clown. 2005. New York: Random House, 2006.

[20]---. The Enchantress Of Florence. London: Jonathan Cape, 2008.

[21] ---. Luka and the Fire of Life. London: Jonathan Cape, 2010.

[22] Rao, Raja. Kanthapura. Delhi: Orient Longman, 1971.

[23] Rushdie, Salman. Interview with Gordon Wise. "A Quiet Anger". Gentleman February 1984: 55-59.

[24] Teverson, Andrew. Salman Rushdie: Contemporary World Writers. Manchester: Manchester UP, 2007. 